\title{
Pembagian Warisan Keluarga Ulama Palangka Raya Dalam Tinjauan Hukum Waris Adat Masyarakat Banjar
}

\author{
Oleh: Dr. Hj. Gusti Muzainah, SH.M.Hum. \\ H. Syaikhu, M.HI \\ E-mail :syaikhu.ahmad.h@gmail.com \\ *'Universitas Islam Negeri Antasari Banjarmasin \\ *2Institus Agama Islam Negeri Palangkaraya
}

\begin{abstract}
Abstrak
Diskursus mengenai hukum - terutama hukum kewarisan selalu menarik untuk dikaji, dalam hubungannya dengan kondisi sosio kultural masyarakat di Indonesia.Hal ini terjadi karena hukum kewarisan yang berlaku di Indonesia masih bersifat pluralistik, maksudnya masing-masing golongan masyarakat mempunyai hukum sendiri-sendiri.Setidaknya ada tiga jenis hukum kewarisan yang masih tetap eksis dan hidup di tengah-tengah masyarakat, yaitu: pertama, hukum kewarisan berdasarkan syari'at Islam, seperti tertuang dalam ilmu faraid kedua, hukum kewarisan adat yang sangat pluralistis keadaannya dan sifatnya tidak tertulis, dan ketiga, hukum kewarisan yang berdasarkan Kitab Undang-Undang Hukum Perdata (KUH Perdata)/BW.Dari ketiga jenis hukum kewarisan yang masih tetap eksis dan hidup di tengah-tengah masyarakat, yang paling dominan dalam pelaksanaan pembagian warisan masyarakat Indonesia adalah berdasarkan hukum Islam dan hukum adat. Hal ini terjadi karena masyarakat Indonesia mayoritas penduduknya beragama Islam dengan berbagai suku yang sangat beragam, yang tentunya pelaksanaan pembagian harta warisan pun akan beragam pula sesuai dengan sistem kekeluargaan yang mereka anut, begitu juga dalam kewarisan masyarakat Banjar.

Key word : pembagian warisan, Ulama, Adat Banjar
\end{abstract}

\section{Abstract}

Discourse on law - especially inheritance law is always interesting to study, in relation to the socio-cultural conditions of people in Indonesia. This happens because the inheritance law in force in Indonesia is still pluralistic in nature, meaning that each group of people has its own law. There are at least three types of inheritance law that still exist and live in the midst of society, namely: first, inheritance law based on Islamic shari'a, as stated in the second faraid science, customary inheritance law which is very pluralistic in nature and unwritten in nature, and third, inheritance law based on the Civil Code (KUH Perdata) / BW. Of the three types of inheritance law that still exist and live in the midst of society, the most dominant in the implementation of the distribution of Indonesian people's inheritance is based on Islamic law and customary law. This happens because the majority of Indonesia's population is Muslim with various very diverse tribes, which of course the implementation of the distribution of inheritance will also vary according to the family system that they profess, as well as in the inheritance of the Banjar community.

Key word: division of inheritance, Ulama, Indigenous Banjar

\section{A. Pendahuluan}

Saat ini pengaturan hukum waris (yang merupakan bagian dari hukum perdata) di Indonesia masih bersifat dualisme dan pluralisme.Hal demikian tidak terlepas dari sejarah hukum berlakunya hukum perdata di Indonesia. Sebelum Indonesia merdeka, sebagai akibat penjajahan kolonial Belanda, politik hukum pemerintah Hindia Belanda pada waktu itu yang dituangkan dalam Pasal I3I dan 163 Indische Staatregeling (IS), terdapat penggolongan hukum dan penggolongan penduduk. Penggolongan ini kemudian berpengaruh terhadap adanya pluralism sistem hukum waris yang berlaku: sistem hukum waris barat, sistem hukum waris adat dan sistem hukum waris Islam.

Keanekaragaman hukum waris tidak sematamata sebagai fenomenanormatif dan politik hukum, melainkan karena faktor sosiologis, kultural,keyakinan dan lain sebagainya. Hukum waris adat juga beraneka ragam, sepertihukum waris menurut susunan masyarakat patrilinial, matrilineal dan parentalyang masing-masing susunan masyarakat tersebut dapat dijumpai perbedaanperbedaandalam hukum kewarisannya, baik berkenaan dengan pengertianpewarisan, obyek pewarisan, pewarisan, penerima waris, cara-cara pewarisan,kewajiban pembagian warisan, pelaksanaan pembagian warisan, hubungan antarapewarisan dengan hak-hak pihak ketiga, hubungan pewarisan dengan hakhakperolehan hak lainnya (seperti hibah, wasiat dll), asas-asas yang mengaturhubungan antara sistem kewarisan yang berbeda yang meliputi asas-asas kalauada sengketa, titik taut antara sistem hukum kewarisan dan obyek atau subyekkewarisan yang tidak berada dalam yurisdiksinya.

Hukum adat dimaknai oleh masyarakat hukum adat secara mendalam, bukan hanya dalam perspektif normatif formal semata sebagaimana terhadap hukum positif. Keberadaan hukum adat yang melekat pada kehidupan masyarakat adat dimaknai sebagai "roh" dari kehidupan masyarakat adat, sehingga aspek normatif yang terwujud dalam petuahpetuah "tetuha" atau tokoh adat hanyalah refleksi dari keyakinan-keyakinan kehidupan yang mereka yakini untuk mewujudkan keselamatan, kedamaian dalam kehidupan masyarakat adat tersebut. Pemaknaan hukum dalam perspektif 
hukum adat yang seperti inilah yang menjadikan hukum adat itu dipatuhi dan dilaksanakan oleh masyarakat dalam kehidupan sehari hari, karena hukum adat bagian sistem kehidupan mereka secara keseluruhan dalam kehidupan. Pengingkaran terhadapnya berarti telah mengingkari kehidupan itu sendiri yang harus mereka tegakan, dan mekanisme penegakan hukum adatpun menjadi unik yang tidak semata berorientasi kepada mereka yang melanggar hukumadat tersebut, akan tetapi juga berorientasi pada pengembalian keseimbangan dalam sistem kehidupan itu sendiri. Hukum adat sebagai suatu sistem hukum yang ada ada masyarakat adat bertujuan mewujudkan tatanan kehidupan yang damai dan tenteram dalam masyarakat, dengan adanya kedamaian dan ketenteraman itulahakan tercipta keadilan hukum bagi mereka.

Bagian-bagian hukum adat besar pengaruhnya terhadap hukum waris adat dan sebaliknya hukum warispun berdiri sentra dalam hubungan hukum-hukum adat lainnya, sebab hukum waris meliputi aturan-aturan hukum yang berlainan dengan proses yang terusmenerus dari abad ke abad, ialah suatu penerusan dan peralihan kekayaan baik materil maupun immamterial dari suatu angkatan ke angkatan berikutnya.

Permasalahan pengaturan hukum waris adat yang berlaku di Indonesia sebagaimana dikemukakan di atas terletak pada pengaturan yang didasarkan pada sistem kekerabatan. Pada sistem kekerabatan menentukan kedudukan ahli waris yang dilihat dari jenis kelamin atau gender para ahli waris. Kedudukan ahli warisberdasar sistem kekeluargaan yang dianut, ini dapat dinilai bersifat diskriminatif, karena pada masyarakat yang menganut sistem patarilinial hanya laki-laki saja yang berkedudukan sebagai ahli waris, sedangkan dalam masyarakat yang menganut sistem kekeluargaan perempuan, yang berkedudukan sebagai ahli waris hanya pihak perempuan. Berbeda dengan sistem kekeluargaan bilateral atau parental, baik perempuan maupun laki-laki sama-sama berkedudukan sebagai ahli waris.

Salah satu suku yang penduduknya beragama Islam di Palangka Raya adalah suku BanjarDi Kalimantan Tengah khususnya, masuk Islam sama dengan masuk Banjaratau sebaliknya masuk Banjar sama artinya masuk Islam. Alfani Daudmenjelaskan bahwa sejak berabadabad yang lalu masyarakat Banjar selalu diidentikkan dengan Islam, dan ini mencerminkan Islam sebagai suatu sistemyang diperpegangi oleh masyarakat Banjar. Dari kecenderungan sumberreferensi perilaku sosial inilah, fungsi keberislaman oleh masyarakat Banjarakhirnya menjadi simbol dan identitas yang membedakan mereka dengankelompok-kelompok masyarakat lain di sekitarnya yang masih menganutkepercayaan atau religi sukunya.
Persoalan yang mendasar adalah, di satu sisi masyarakat Banjar itu menganut agama Islam dan terkenal fanatik (tidak ada masyarakat Banjar yang beragama selain Islam), tetapi di sisi lain terdapat fenomena yang justru tidak mengarah kepada hukum waris Islam normatif yang ada dalam al-Qur'an dan sunnah. Mereka lebih mengarah kepada hukum waris adat, seperti kecenderungan untuk tidak membedakan bagian anak laki-laki dan anak perempuan dalam menerima warisan. Selain itu, dalam pengematan juga ditemukan adanya harta warisan yang belum dibagi, padahal di dalam Islam dianjurkan untuk segera dibagi agar tidak terjadi sengketa di kemudian hari.Agar pembahasan lebih terfokus, peneliti hanya membatasi pelaksanaan pembagian harta warisan dalam keluarga ulama saja.Pembatasan ini dilakukan mengingat dalam tatanan masyarakat Banjar, ulama memegang peranan yangsangat signifikan dalam kehidupan masyarakat Banjar di Palangka Raya.

Penyebutan gelar mu'allim, guru, dan tuangurusepenuhnya menjadi hak dan otoritas dari masyarakat, artinya meskipun berasal dari keluarga biasa, kalau masyarakat menganggapnya pantas untuk mendapatkan gelar itu, maka dengan sendirinya gelar itu melekat di dalam dirinya. Demikian juga sebaliknya, meskipun anak atau keturunan seorang mu'allim, guru, dan tuan guru, tetapi kalau masyarakat menganggapnya belum pantas untuk menerima gelar tersebut, maka gelar mu'allim, guru, dan tuan guru tidak akan melekat didalam dirinya. Hal ini menggambarkan bahwa dalam masyarakat (suku) Banjar, seseorang itu dihormati dan dimuliakan karena kapasitas keilmuannya bukan karena keturunannya. Oleh karena itu, dalam tatanan masyarakat Banjar diketahui bahwa apabila seseorang itu berpredikat sebagai mu'allim, guru, dan turn guru, belum tentu orang tua maupun anak-anaknya juga berpredikat seperti itu. Jadi, dalam masyarakat Banjar di Palangka Raya, penyebutan gelar mu'allim, guru, dan tuan guru itu ditentukan berdasarkan pengakuan masyarakat, kapasitas pengetahuan agama yang dimiliki, dan peran yang dimainkan dalam masyarakat.

Oleh karena itu, sangat strategis jika ada upaya untuk mengetahui tentang pembagian harta warisan dalam keluarga ulama Banjar di Palangka Raya sebagai barometer bagi masyarakat Banjar yang religius dalam melaksanakan pembagian warisan dalam keluarganya.

\section{B. Sistem Kewarisan Dalam Hukum Adat}

$\mathrm{Di}$ bawah ini penulis akan menguraikan tiga sistem kewarisan menurut hukum Adat Indonesia yaitu: a. Sistem Kewarisan Individual

Ciri Sistem Kewarisan Individual, ialah bahwa harta peninggalan itu terbagi-bagi pemilikannya kepada para waris, sebagaimana berlaku menurut 
KUH Perdata (Kitab Undang-Undang Hukum Perdata), dan Hukum Islam, begitu pula berlaku di lingkungan masyarakat adat seperti pada keluargakeluarga Jawa, yang parental, atau juga padakeluargakeluarga Lampung yang patrilineal. Pada umumnya sistem ini cenderung berlaku di kalangan masyarakat keluarga mandiri, yang tidak terikat kuat dengan hubungan kekerabatan.Pada belakangan ini di kalangan masyarakat adat yang modern, di mana kekuasaan penghulu-penghulu adat sudah lemah, dan tidak ada lagimilik bersama, sistem ini banyak berlaku.

Kebaikan sistem individual ini adalah dengan adanya pembagian, maka pribadi-pribadi waris mempunyai hak milik yang bebas atas bagian yang telah diterimanya. Para waris bebas menentukan kehendaknya atas harta warisan yang menjadi bagiannya, ia bebas untuk mentransaksikan hak warisannya itu kepada orang lain. Kelemahannya, ialah bukan saja pecahnya harta warisan, tetapi juga putusnya hubungan kekerabatan antara keluarga waris yang satu dan yang lainnya. Hal mana berarti, lemahnya asas hidup kebersamaan dan tolongmenolong antara keluarga yang satu dan keluarga yang lain yang seketurunan.

b. Sistem Kewarisan Kolektif

Ciri sistem kewarisan kolektif, ialah bahwa harta peninggalan itudiwarisi/dikuasai oleh sekelompok waris dalam keadaan tidak terbagibagi,yang seolah-olah merupakan suatu badan hukum keluarga kerabat(badan hukum adat). Harta peninggalan itu di sebut hartou menyayanakdi Lampung, dalam bentuk bidang tanah kebun atau sawah, atau rumahbersama (di MinangkabauGedung).

c. Sistem Kewarisan Mayorat

Ciri sistem kewarisan mayorat, adalah bahwa harta peninggalan orangtua atau harta peninggalan leluhur kerabat tetap utuh tidak dibagi-bagikepada para waris, melainkan dikuasai oleh anak tertua lakilaki(mayorat laki-laki) di lingkungan masyarakat patrilineal Lampung danjuga Bali, atau tetap dikuasai anak tertua perempuan (mayorat wanita)di lingkungan masyarakat matrilineal semendo di Sumatera Selatan danLampung.Bagi masyarakat adat Lampung Pesisir, penduduknya menggunakansistem kewarisan mayorat laki-laki. Sistem kewarisan mayorat hamper sama dengan sistem kewarisan kolektif, hanya penerusan danpengalihan hak penguasa atas harta yang tidak terbagi-bagi itudilimpahkan kepada anak tertua yang bertugas sebagai pemimpinrumah tangga atau kepala keluarga menggantikan kedudukan ayah atauibu sebagai kepala keluarga.

Diserahkannya hak penguasaan atas seluruh harta kepada anak laki-lakitertua, bagi masyarakat
Adat Lampung Pesisir, maksudnya adalahsebagai penerus tanggung jawab orang tua yang wafat, untukbertanggung jawab atas harta peninggalan dan kehidupan adik-adiknyayang masih kecil, hingga mereka dapat berdiri sendiri. $\mathrm{Di}$ daerahLampung yang memimpin, mengurus, dan mengatur penguasaan hartapeninggalan adalah anak punyimbang, yaitu anak lelaki tertua dari isteritertua.

Kelemahan dan kebaikan sistem kewarisan mayorat, adalah terletakpada kepemimpinan anak tertua dalam kedudukannya sebagaipengganti orang tua yang telah wafat, dalam mengurus harta kekayaandan memanfaatkannya guna kepentingan semua anggota keluarga yangditinggalkan. $\mathrm{Hal}$ ini disebabkan, karena anak tertua bukanlah sebagaipemilik harta peninggalan secara perseorangan, tetapi sebagaipemegang mandat orang tua yang dibatasi oleh musyawarah keluarga,dibatasi oleh kewajiban mengurus orang tua yang dibatasi olehmusyawarah keluarga lain, dan berdasarkan atas tolong-menolong olehbersama untuk bersama.

\section{Hukum Waris Adat Masyarakat Banjar}

Masyarakat Suku Banjar mayoritas memeluk Agama Islam.Hal ini tentunya mempengaruhi segala kegiatan yang terjadi di dalam masyarakat Suku Banjar itu sendiri.Meskipun sebagai penganut agama Islam yang cukup taat, tetapi dalam pelaksanaannya tidak sepenuhnya Hukum Islam ini dapat diterapkan karena masih kuatnya pengaruh adat dari masyarakat setempat.Adanya dua pengaruh hukum ini yakni Hukum Islam dan Hukum Adat, maka sering kali menimbulkan berbagai persoalan di mana adanya pilihan hukum antara kedua sistem hukum ini yakni apakah tetap menerapkan Hukum Adat yang selama ini masih berlaku atau kah dengan menerapkan Hukum Islam sebagai hukum dari agama yang secara mayoritas dianut masyarakat Suku Banjar.

Hukum waris adat adalah hukum adat yang memuat garis-garis ketentuan tentang sistem dan asasasas hukum waris, tentang harta warisan itu dialihkan penguasaan dan pemilikkannya dari pewaris kepada ahli waris.Hukum waris adat sesungguhnya adalah hukum penerusan harta kekayaan dari suatu generasi kepada keturunannya.

Menurut Soepomo : "Hukum adat waris memuat peraturan-peraturan yang mengatur proses meneruskan serta mengoperkan barang-barang harta benda dan barang-barang yang tidak berwujud benda dari suatu angkatan manusia kepada turunannya".

Dalam teori hukum Islam, adat yang dapat diterima hanyalah adat yang baik, sementara yang buruk harus ditolak bahkan dihilangkan. Dalam konteks inilah, para yuris muslim memformulasikan berbagai kaedah hukum yang berkaitan dengan adat, seperti al- 'adah 
muhakkamah (adat kebiasaan itu bisa menjadi hukum), alsabit bi al-'urf ka al-sabit bi al-nas (yang ditetapkan melalui 'urf sama dengan yang ditetapkan melalui nas).

Pada proses pembagian warisan pada masyarakat Banjar terdapat peran tokoh masyarakat yang disebut "tetuha kampung" atau "tuan guru" atau "abah guru", yaitu tokoh yang dianggap mengetahui permasalahan agama, termasuk dalam masalah warisan. Posisi sentral tokoh masyarakat ini menjadikannya sangat berperan dalam proses penentuan ahli waris dan proses pembagian warisan. Adapun adat yang berlaku pada masyarakat Banjar, manakala terjadi peristewa hukum yang membawa akibat hukum pada adanya hak waris, maka pihak keluarga akan mendatangi tokoh masyarakat ini untuk berkonsultasi, sekaligus meminta pendapat tentangsiapa-siapa saja yang menjadi ahli waris dan besarnya bagiannya masing-masing. Umumnya yang mendatangi tokoh masyarakat ini adalah laki-laki atau saudara tertua yang ada dikeluarga, oleh karena itu akses perempuan terhadap tuan guru atau tokoh masyarakat ini lebih kecil dibandingkan dengan laki-laki, sehingga ada dalam beberapa kasus informasi yang diberikan oleh pihak yang berkonsultasi ke tuan guru ini menjadi tidak seimbang.

Karakter agama Islam dalam pembagian faraidh tentunya membawa konsekwensi apakah dalam permasalahan pembagian warisanberlaku pula syariat islam, yaitu apakah pembagian waris antara ahli waris laki-laki dan ahli waris perempuan mengacu kepada ketentuan yang tertuang dalam Al-Qur'an sebagaimana yang diatur dalam Qur'an Surah An Nisa ayat (I I) yang menentukan bahwa "laki-laki memperoleh bagian dua kali dari bagian perempuan". Hasil penelitian menunjukan dalam masyarakat Banjar ternyata diperoleh data bahwa bagian perempuan tidak selalu menerima bagian harta warisan yang lebih sedikit dari pada pihak laki-laki. Dalam menerima harta warisan bisa dikualifikasi sebagai berikut (a) Perempuan mendapatkan bagian lebih sedikit dari pada bagian lakilaki; (b)Perempuan mendapatkan bagian yang sama dengan bagian laki-laki; (c) Perempuan mendapatkan bagian yang lebih besar dari bagian laki-laki.Adanya variasi bagian harta wartisan terhadap perempuan yang seperti ini disebabkan oleh adanya penetapan bagian harta warisan didasarkan kepada asas atau prinsip "manfaat" atau "kemanfaatan".

Kalau seandainya ada orang tua yang merasa bahwa ketetapan Allah tersebut tidak menjadi adil apabila dia telah memenuhi banyak kebutuhan anak lakilakinya, maka jalan keluar yang dapat ditempuh adalah memberi anak perempuannya semasa hidup dan sehatnya - jumlah yang dianggapnya dapat menghasilkan keadilan di antara anak-anaknya. Allah memberi wewenang kepada pemilik harta semasa hidup dan sehatnya untuk menggunakan hartanya sesuai kehendaknya dalam bat as yang halal dan adil.Apabila dia meninggal dunia, maka dia tidak lagi memiliki wewenang dan harta tersebut menjadi milik Allah, dan hanya Dialah yang berwenang penuh membaginya sebagaimana ditetapkan-Nya dalam ketentuan hukum waris.

Kata mufakat yang dihasilkan berdasarkan musyawarah, kadang-kadang mengakibatkan adanya perbedaan bagian yang diterima oleh ahli waris dengan bagian menurut yang ditentukan dalam Islam. Walaupun demikian, semangat atau jiwa dari hukum kewarisan Islam tidak ditinggalkan, artinya pada ahli waris ada kesadaran mengenai bagian yang mesti didapat berdasarkan angka-angka faraid, tetapi sering kali hal itu disubordinasikan (ditarik ke belakang) dengan memberikan kesempatan bagi prinsip "kerelaan" untuk lebih berperan.

Dalam kewarisan adat Banjar juga dikemukakan bahwa tidak ditemukan adanya suatu keharusan untuk membagi harta warisan, akan tetapi pembagian harta warisan dilakukan dilihat dari situasi atau keadaan tertentu yang menghendaki segera atau tidaknya harta warisan itu dibagi.

\section{Pembagian Harta Warisan Dalam Keluarga Ulama}

Implementasi dari ajaran Islam pada kehidupan masyarakat Banjar jugasangat dipengaruhi dan didominasi oleh para alim ulama, apa-apa yang merekafatwakan akan dituruti oleh masyarakat sebagai suatu acuan dalammenyelesaikan masalah kehidupannya.Dari ini jelas bahwa dalam masyarakat.Banjar sejak dulu telah mempunyai semacam hasil ijtihad ulama dalammasalahmasalah hukum sesuai dengan kondisi dan situasi daerah sertadiperpegangi oleh masyarakat.

Dalam al-Qur'an dan kitab-kitab fikih sendiri sudah dijelaskan tentang bagian yang diterima oleh ahli waris. Bahkan ketika salah satu ahli waris masih berada dalam kandungan pun ada tata cara pembagiannya (padahal jenis kelaminnya masih belum jelas). Anak yang masih berada dalam kandungan ibunya termasuk ahli waris yang berhak menerima warisan sebagaimana ahli waris lainnya.

Sistempewarisan yang dilakukan oleh sebagian keluarga ulama Banjar di Palangka Raya juga menganut sistem pewarisan mayorat.Walaupundemikian, sistem mayorat yang terjadi dalam keluarga ulama ini dilakukankarena adanya pertimbangan-pertimbangan tertentu untuk tidak membagiharta warisan yang didasarkan kepada wasiat atau kesepakatan ahli warisdalam rangka menjaga kemaslahatan bersama.Oleh karena itu, model sistempewarisan mayorat yang dijumpai dalam keluarga ulama Banjar di Palangka Raya ini dapat dikatakan sebagai suatu pengecualian 
ataupenyimpangan khusus dari sistem warisan yang individual.

Konsep kewarisan masyarakat Banjar di Palangka Raya dimana hal itu terjadi ketika masih ada ahli waris yang masih kecil atau masih hidupnya pasangan hidup pewaris. Ketika pasangan hidup pewaris (janda/duda) masih hidup, para ahli waris yang lain dalam rangka menghormati orang tuanya merasa tidak tega membagi harta yang ditinggalkan. Mereka yang menggugat untuk membagi harta peninggalan tersebut, oleh masyarakat digolongkan sebagai anak yang tak tahu diri (durhaka). Oleh karena itu merupakan pantangan membagi harta peninggalan sementara salah seorang dari orang tua mereka masih ada.

Harta warisan tersebut biasanya dikuasai oleh salah seorang ahli waris.Penguasaan harta warisan oleh salah seorang ahli waris ini biasanya dilakukan oleh orang tua laki-laki atau orang tua perempuan kalau salah satunya meninggal dunia, atau dikuasai oleh saudara tertua kalau kedua orang tuanya meninggal dunia. Ada beberapa alasan sehingga harta warisan tersebut belum dibagi, seperti:

I. Calon pewaris berwasiat (berpesan) sebelum meninggal agar jangan sampai terjadi pertengkaran mengenai harta warisan, dimana harta warisan dinikmati secara bersama-sama saja. Dalam hal ini biasanya harta warisan berupa rumah dan perahu, sehingga dengan demikian setiap ahli waris dapat menikmati hasilnya atau menggunakannya.

2 Ahli waris mempunyai kesepakatan untuk tidak membagi sebagian atau seluruh harta warisan, dengan tujuan agar harta tersebut dapat digunakan untuk melaksanakan upacara keagamaan yang terjadi sehubungan dengan meninggalnya pewaris, seperti upacara haulan setiap tahun.

3. Ahli waris bersepakat harta warisan tidak dibagi dalam rangka membiayai ahli waris yang belum mandiri atau ahli waris lain dianggap belum dewasa atau cakap mengurus sendiri bagian harta warisan yang merupakan haknya.

4. Ahli waris sepakat untuk tidak membagi harta warisan karena menghormati salah satu ahli waris lain yaitu ibunya atau bapaknya, sehingga jarang sekali adanya tuntutan membagi harta warisan dari anakanaknya walaupun anak-anak tersebut sudah dewasa.

Pembagian warisan dengan cara Musyawarah (islah) yang terjadi dalam keluarga ulama Banjar ini biasanya dilakukan oleh para ahli waris untuk mencapai kemufakatan di antara mereka, sehingga hubungan kekeluargaan tetap terjalin dengan baik. Pembagian harta warisan dengan caraislah atau dengan cara musyawarah mufakat ini, berarti prosesnya hanya menempuh satu cara, yaitu musyawarah mufakat. Dalam hal ini, ahli waris bermusyawarah menentukan besarnya bagian masingmasing ahli waris dan penerima warisan lainnya.Dalam islah ini, pertimbangan-pertimbangan yang menentukan besarnya bagian masing-masing ditentukan oleh kondisi objektif keadaan ahli waris dan penerima warisan lainnya.Oleh karena itu bagian yang diterima oleh masingmasing ahli waris dan penerima warisan lainnya sangat variatif, karena tidak memakai prosentasi tertentu.Sebagian ulama Banjar di Palangka Raya menganggap bahwa islah juga dibenarkan oleh syariat Islam, karena warisan termasuk bidang muamalah yang pelaksanaannya diserahkan kepada umat, asalkan dalam hal tersebut tidak ada perselisihan. Dalam hal ini mereka melakukan pembagian warisan berdasarkan apa yang mereka sepakati secara damai dan didasarkan pada kemaslahatan mereka. Bagi mereka yang terpenting adalah kesepakatan dalam membagi harta warisan dan tidak terjadi sengketa atau perselisihan, namun apabila terjadi perselisihan di antara mereka maka islah tidak dilaksanakan, tetapi merujuk kepada pembagian harta warisan menurut faraid.

\section{E. Penutup}

Hukum waris yang ada dan berlaku di Indonesia hingga saat ini belum mempunyai unifikasi hukum.Karena hukum yang ada di Indonesia beragam dan pastinya masyarakat Indonesia sendiri mengikuti hukum yang berlaku, yaitu hukum Barat (hukum positif), Islam dan Adat.Akibatnya sampai saat ini pengaturan masalah waris di Indonesia belum mempunyai kesamaan.

Dalam pengamatan, bahwa sebagian ulama Banjar di Kota Palangka Raya menganggapbahwa islah dalam pembagian harta warisandibenarkan oleh syariat Islam, karena warisan termasuk bidang muamalah yang pelaksanaannya diserahkan kepada umat, asalkan dalam hal tersebut tidak ada perselisihan. Mereka melakukan pembagian warisan berdasarkan apa yang mereka sepakati secara damai dan didasarkan pada kemaslahatan mereka. Hal terpenting adalah kesepakatan dalam membagi harta warisan dan tidak terjadi sengketa atau perselisihan, namun apabila terjadi perselisihan di antara mereka maka islah tidak dilaksanakan, tetapi merujuk kepada pembagian harta warisan menurut faraid. Prinsip perdamaian (islah) adalah cara yang dapat dibenarkan, agar suasana persaudaraan dapat terjalin dengan baik, sepanjang perdamaian itu tidak dimaksudkan untuk mengharamkan yang halal dan menghalalkan yang haram.

\section{DAFTAR PUSTAKA}

Alfani Daud, Islam dan Masyarakat Banjar Diskripsi dan Analisa Kebudayaan Banjar (Jakarta: Raja Grafindo Persada, 1997)

Ahmad Roflq, Fiqh Mawaris EdisiRevisi(Jakarta: Raja Grafindo Persada, 2002) 
Bushar Muhammad, Pokok-Pokok Hukum Adat, Jakarta: PT. Pradnya Paramitha, 2002)

Fatchur Rahman, Ilmu Waris (Bandung: Al-Maarif, 1994)

Gusti Muzainah , Prinsip Prinsip Hukum Kedudukan Perempuan Dalam Hukum Waris Adat Masyarakat Banjar, Jurnal Ilmu Hukum Pebruari 2012, Vol. 8, No. I5 -,Prinsip Hukum Kedudukan Perempuan Dalam Hukum Waris Adat Masyarakat Banjar, Mu'adalah Jurnal Studi Gender dan Anak Vol. II No. I, Januari-Juni 2014

Hilman Hadikusuma, Hukum Waris Adat, (Bandung: Citra Aditya Bakti, 2003)

Komari. 201I. Laporan Akhir Kompidium Hukum Waris. Jakarta: Badan Pembinaan Hukum Nasional Departemen Hukum dan Hak Asasi Manusia

M. Quraish Shihab, Perempuan Dari Cinta sampai Seks dari Nikah Mut'ah sampaiNikah Sunnah Dari Bias lama sampai Bias Baru (Cet. II; Jakarta: LenteraHati, 2005)

M. Toha Abdurrahman, Pembahasan Wans dan Wasiat Menurut Hukum Islam (Yogyakarta: t.p., 1976)

Umar Syihab, Hukum Islam dan Transformasi Pemikiran (Semarang: Bina Utama, 1996)

Soejono Soekanto, Hukum Adat Indonesia, (Jakarta: Raja Grafindo Persada, 2012) 